"Hiding in Plain Sight is a wonderfully comprehensive and clearly worded work that everyone should read. If you want to understand the war criminals of modern times and the dogged pursuit of justice for them, this is the only book you need to read, and you must read it."

- Peter Maass, author of Love Thy Neighbor: The Story of War

"Hiding in Plain Sight deals a much-needed blow to impunity by revealing how governments and international institutions have sometimes succeeded-but more often failed-to live up to their legal obligations to bring war criminals to justice. This thoroughly researched book is both extremely timely and long overdue.”

- Navi Pillay, former United Nations High Commissioner for Human Rights and former President of the International Criminal Tribunal for Rwanda

"The cycle of impunity for atrocity crimes is closing slowly but surely. Telling a complex story in a highly readable way, the authors make their own significant contribution to accountability and justice for human rights crimes. The torturer still runs, but he can no longer hide."

— Juan Mendez, UN Special Rapporteur on Torture

"A riveting modern history, on the trail of international justice in the face of politics and self-interest, Hiding in Plain Sight is a must-read for anyone who wants to know from whence we have come and the obstacles that will fill the road that lies ahead."

- Philippe Sands, author of Torture Team: Uncovering War Crimes in the Land of the Free 
This page intentionally left blank 
Hiding in Plain Sight 
This page intentionally left blank 


\section{Hiding in Plain Sight}

The Pursuit of War Criminals from

Nuremberg to the War on Terror

\section{Eric Stover \\ Victor Peskin \\ Alexa Koenig}

甲 
University of California Press, one of the most distinguished university presses in the United States, enriches lives around the world by advancing scholarship in the humanities, social sciences, and natural sciences. Its activities are supported by the UC Press Foundation and by philanthropic contributions from individuals and institutions. For more information, visit www.ucpress.edu.

University of California Press

Oakland, California

(C) 2016 by The Regents of the University of California

Library of Congress Cataloging-in-Publication Data

Stover, Eric, author.

Hiding in plain sight : the pursuit of war criminals from Nuremberg to the War on Terror / Eric Stover, Victor Peskin, Alexa Koenig. - First edition.

pages $\mathrm{cm}$

Includes bibliographical references and index.

ISBN 978-0-520-27805-9 (cloth : alk. paper) - ISBN 0-520-27805-4 (cloth : alk. paper) — ISBN 978-0-52027806-6 (pbk. : alk. paper) - ISBN 0-520-27806-2 (pbk. : alk. paper) - ISBN 978-0-520-96276-7ISBN O-520-96276-I

I. War crime trials. 2. War crimes investigation. 3. International criminal courts. I. Peskin, Victor, I967- author. II. Koenig, Alexa, I972-

author. III. Title.

KZII 68.5.S76 20I6

$34 \mathrm{I} .6^{\prime} 9-\mathrm{dc} 23$

2015028398

Manufactured in the United States of America

$\begin{array}{llllllllll}25 & 24 & 23 & 22 & 2 I & 20 & \text { I9 } & \text { I8 } & \text { I7 } & \text { I6 }\end{array}$

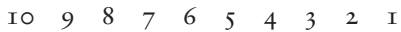

In keeping with a commitment to support environmentally responsible and sustainable printing practices, UC Press has printed this book on Natures Natural, a fiber that contains $30 \%$ post-consumer waste and meets the minimum requirements of ANSI/NISO Z39.48-I992 (R I997) (Permanence of Paper). 
In memory of Clyde Snow 
This page intentionally left blank 